\title{
Physico- chemical characterization and associated antioxidant capacity of fiber concentrates from Moroccan date flesh
}

\author{
A. Hasnaoui ${ }^{1 *}$. M. A. Elhoumaizi ${ }^{1}$, C. Borchani ${ }^{2}$, H. Attia ${ }^{2}$ and S. Besbes ${ }^{2}$ \\ ${ }^{1}$ Université Mohamed $1^{\text {er, }}$ Faculté des Sciences, BP 717 Oujda, Maroc. \\ ${ }^{2}$ Unité Analyses Alimentaires, Département de Biologie, Ecole Nationale d'Ingénieurs de Sfax, \\ Route de Soukra BPW 3038 Sfax, Tunisie. \\ astaghfir@gmail.com, 1elhoumaizi@yahoo.fr, borchani_chema@yahoo.fr, hamadi.attia@enis.rnu.tn, \\ besbes.s@voila.fr
}

\begin{abstract}
The aim of this research was to investigate physico-chemical and some functional properties (water and oil holding capacity, emulsion capacity and stability) and associated antioxidant capacity of date fiber concentrates (DFC) from five potential Moroccan cultivars. The main chemical composition of date flesh was also analyzed. Date flesh had high amount of reducing sugars (fructose and glucose), total and insoluble dietary fiber and natural antioxidants (polyphenol and flavonoid). DFC exhibited high proportions of insoluble dietary fiber and presented a relatively low amount of protein, ash, fat, total phenolic and total flavonoid content. DFC also showed high water-holding and oil-holding capacities ( 6.1- $8 \mathrm{~g}$ water $/ 100 \mathrm{~g}$ and $5.34-6.4 \mathrm{~g}$ oil/ $100 \mathrm{~g}$, respectively). Emulsion capacity of DFC was in the range of 17.5 to $23 \mathrm{ml} / 100 \mathrm{ml}$. DFC showed also high emulsion stability ( $34.5-38 \mathrm{ml} / 100 \mathrm{ml})$. DFC was shown to possess an antiradical capacity. In fact, antiradical efficiency (AE) ranged between 1.26 and $7.09 \times 10^{-3}$ of DFC, which were considered suitable for antioxidant dietary fiber production. Findings of this investigation revealed essential information that could be advance the possibility to use DFC as an ingredient for the food industry.
\end{abstract}

Keywords: Moroccan date, Date fruit, Date chemical composition; date fiber concentrates; antioxidant capacity.

\section{Introduction}

The fruits of the date palm (Phoenix dactyliferaL.) are very commonly consumed in many parts of the world and a vital component of the diet and a staple food in most of the Arabian countries. Date fruits pass through several distinct stages of ripening, the Arabic terms- Kimri, Khalal, Rutab and Tamar- are used to represent, respectively, the immature green, the mature full colored, the soft brown and the hard raisin-like stages of development (Barreveld, 1993; Ahmed \& Ahmed, 1995). In Moroccan oases, dates are consumed at the Tamar stage probably because of its good storability, sweet taste and lower astringency.

The production of dates in the Arab countries accounts for $82.25 \%$ of the total world production while Morocco is the $13^{\text {th }}$ date producing country with an average annual production of 72.700 tons (FAOSTAT, 2009). In Figuig oasis located at the South-East region, the estimated number of date palm trees is 190.000 representing $2.8 \%$ of total Moroccan date palm agricultural areas (Hakkou\&Bouakka, 2004). In this oasis, the date production faces a wide range of problems, including the predominance of low quality dates and absence of their transformation industries, inadequate packaging, inappropriate preservation methods and changes in local consumers' habits.

As revealed by several publications, dates flesh is rich in sugars (glucose, fructose and sucrose), dietary fibers, minerals, protein and vitamins (Sawayaet al.,1983; Ahmed \& Ahmed, 1995; Al-Hootiet al.,1995; Aidooet al., 1996; Ismailet al., 2006; El Aremet al., 2011). In recent decades, the interest in food rich in dietary fiber (DF) increased and the importance of this food constituent has led to the development of a large market for fiber - rich products. Among the different fiber-rich foods, dates fruits are one of the main sources of DF. The amount of DF coming from date fruits differs to a great extent depending on the cultivar, the ripening stage, analytical methods and processing conditions. Holland et al. (1991) reported that the DF content ranged from $6.5 \%$ by Southgate method to $3.4 \%$ by Englyst method. AlMukhtar (1994), using an enzymatic method, showed that the DF for combined dates of cvs. Hallawi and Sayer was $8 \%$. Limited information on Moroccan date's fruit and its ability to transformation on new products are available in the literature and, therefore, studies on date flesh are relevant to generate physicochemical parameters that would help the process industry to design new food products, quality control and development of date'ssector in Morocco. In this paper, chemical composition of date flesh of the most produced and consumed cultivars (Assiane, Aziza bouzid, Boufeggous, Boufeggousgharas and Mejhoul ) from Figuig oasis located in South-East of Morocco, was investigated. The corresponding date fibers concentrates (DFC) of those five cultivars were extracted and their chemical composition as well as some functional and antioxidant properties were also investigated to promote the industrial use of dates as a new source for the production of fiber concentrates.

\section{Material and methods}

\section{Plant material}

Five Moroccan cultivars of date fruit, namely Assiane, Aziza bouzid, Boufeggous, Boufeggousgharas and Mejhoul 1 were procured from Figuig oasis and one cultivar Mejhoul 2 from Tafilalet region. The fruits were collected at Tamar stage (full ripeness) at the end of A. Hasnaoui et al. Indian J.Sci.Technol. 
2009 harvest season. They were sorted, cleaned, pitted and stored in a refrigerator at $\pm 4^{\circ} \mathrm{C}$ for three months until analysis.

\section{Extraction of dietary fibers (DF)}

Extraction procedures used were according to the method of Borchani et al. (2010). Date fiber concentrates (DFC) were extracted from a mixture of hot water and date paste with a relative dates / water $=1: 6(\mathrm{w} / \mathrm{v})$. The mixture was kept at $70{ }^{\circ} \mathrm{C}$ for 15 minutes in a stainless steel pot and then filtered through a fine mesh of 0.318 $\mathrm{mm}$ diameter to separate insoluble residues. These extraction and filtration were repeated 7 times until the residue was completely free of sugars. The insoluble residue obtained was dried and milled to give the DFC then stored at $\pm 4^{\circ} \mathrm{C}$ for 7 days until physicochemical analysis.

Physico-chemical analysis of date pulp and date fiber concentrates (DFC)

Proximate composition (dry matter, ash, lipid and protein content) was determined according to the method described by Association of Official Analytical Chemists (AOAC, 1997). Protein was analyzed according to Kjeldahl method (AOAC, 1997) and factor 6.25 was used for conversion from total nitrogen to crude protein. Lipid content was determined by Soxhlet extraction using petroleum ether solvent (AOAC, 1997).

Total soluble sugars were assessed by the dinitrosalicylic acid (DNS) method (Miller, 1959). Concentrations of insoluble and soluble dietary fibers were determined according to Englyst method (Englystet al., 1994).

Water activity $\left(a_{w}\right)$ of date flesh was measured at $25^{\circ} \mathrm{C}$ by a Novasina Aw Sprint apparatus (Novasina Aw Sprint TH-500, Switzerland).

The concentration of total phenolics, expressed as gallic acid equivalents (GAE mg/ $100 \mathrm{~g}$ of sample, dry weight), was determined colorimetrically using FolinCiocalteau reagent as described by Al-Farsi et al. (2005) using a UV-1601 spectrophotometer (Shimazu).

Total flavonoid content of date flesh and DFC was determined according to Zhishenet al. (1999). One $\mathrm{ml}$ of the extract was placed in a $10-\mathrm{ml}$ volumetric flask containing $5 \mathrm{ml}$ distilled water. Then $0.3 \mathrm{ml}$ of $5 \%$ sodium nitrite was added; after $5 \mathrm{~min}, 0.3 \mathrm{ml}$ of $10 \%$ aluminum chloride was added. After $6 \mathrm{~min}, 2 \mathrm{ml}$ of $1 \mathrm{M}$ sodium hydroxide were added and diluted to volume with distilled water. Immediately the solution absorbance was measured at $510 \mathrm{~nm}$ using a spectrophotometer. Measurements were calibrated to a standard curve of prepared quercetin solution and the total flavonoid content was expressed as quercetin equivalents (QEQ $\mathrm{mg} / 100 \mathrm{~g}$ of sample, dry weight).

The capacity of extracts from DFC to reduce the radical 2, 2-diphenyl-1- picrylhydrazyl (DPPH) was assessed using the method of Masuda et al. (1999) with some modification. One hundred fifty $\mu \mathrm{l}$ of a solution of DPPH in methanol $(0.004 \%)$ were mixed with $1 \mathrm{ml} \mathrm{DFC}$ extract during $30 \mathrm{~min}$ and the absorbance was recorded at $517 \mathrm{~nm}$. The scavenging activity of extracts was evaluated according to the formula: percent scavenging = $\left.\left[A_{0}-\left(A_{1}-A_{S}\right)\right] / A_{0}\right] \times 100$, where $A_{0}$ is the absorbance of DPPH alone, $A_{1}$ is the absorbance of DPPH + extract and $A_{S}$ is the absorbance of the extract only. The parameter EC50, which reflects $50 \%$ depletion of DPPH free-radical, was expressed in terms of grams of date fiber concentrates equivalent per gram of DPPH in the reaction medium. The time necessary to reach the steady state at EC50 (TEC50) was calculated. The antiradical efficiency (AE), an index defined by Sanchez-Moreno et al. (1998) which combines both factors, was also calculated in order to recognize the combined effect of both parameters: $\mathrm{AE}=1 / \mathrm{EC}_{50} \mathrm{TEC}_{50}$.

Analysis of some techno-functional properties of DFC

Water-holding capacity (WHC): Water-holding capacity (WHC) was determined according to Robertson et al. (2000). One hundred $\mathrm{mg}$ of DFC were added to $10 \mathrm{ml}$ distilled water and stirred overnight at $4^{\circ} \mathrm{C}$. Then the mixture was centrifuged in $50 \mathrm{ml}$ graduated tube at $14,000 \mathrm{~g}$ for $20 \mathrm{~min}$. Water-holding capacity (WHC) was expressed as $\mathrm{g}$ of water held per $\mathrm{g}$ of sample.

Oil-holding capacity $(\mathrm{OHC})$ : Oil-holding capacity $(\mathrm{OHC})$ was determined according to Lin et al. (1974). In $50 \mathrm{ml}$ graduated centrifuged tube, $100 \mathrm{mg}$ of DFC were mixed with $15 \mathrm{ml}$ of corn oil. The prepared solution was homogenized for 30 second every $5 \mathrm{~min}$ for $30 \mathrm{~min}$ and then centrifuged for $25 \mathrm{~min}$ at $1600 \mathrm{~g}$. The supernatant obtained was carefully removed. $\mathrm{OHC}$ was expressed as $\mathrm{g}$ of oil held per $\mathrm{g}$ of sample.

Emulsion capacity (EC): Twenty $\mathrm{ml}$ of $7 \%(\mathrm{w} / \mathrm{v})$ sample suspension, prepared beforehand and $20 \mathrm{ml}$ of the corn oil were stirred for $5 \mathrm{~min}$ and then centrifuged in $50 \mathrm{ml}$ graduated tube at $3000 \mathrm{~g}$ for $5 \mathrm{~min}$ (Yasumatsuet al., 1972). Emulsion capacity was calculated as the ratio of the volume of emulsified layer in the supernatant and the volume of whole layer in centrifuged tube.

Emulsion stability (ES): Emulsion stability was evaluated according to Chauet al (1997). Emulsions prepared by the above procedures were heated at $80^{\circ} \mathrm{C}$ for $30 \mathrm{~min}$, cooled to room temperature and centrifuged in $50 \mathrm{ml}$ graduated tube at $1200 \mathrm{~g}$ for $5 \mathrm{~min}$. ES was calculated as volume of remaining emulsified layer in the supernatant loriginal emulsion volume.

\section{Experimental design and statistical analysis}

Means were based on three replications. Values of different parameters were expressed as the mean \pm standard deviation. Student - Newman - Keuls test was performed using statistical analysis package SPSS 10.0 for Windows (SPSS Inc., Chicago, USA) at $p<0.05$, to evaluate the significance of differences between mean values.

\section{Results and discussion}

\section{Proximate composition of date flesh}

The proximate composition of date fleshes of the five studied cultivars are given in Table 1. All cultivars 
Indian Journal of Science and Technology

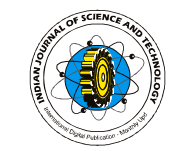

Table 1. Chemical composition of studied date fleshes

\begin{tabular}{|l|l|l|l|l|c|l|}
\hline Component & Assiane & Aziza bouzid & Boufeggous & Boufeggousgharas & Mejhoul 1 & Mejhoul 2 \\
\hline Dry matter (\%) & $73.91^{\mathrm{e}} \pm 0.98$ & $71.63^{\mathrm{d}} \pm 0.03$ & $63.46^{\mathrm{c}} \pm 0.017$ & $74.51^{\mathrm{f}} \pm 0.06$ & $\begin{array}{c}59.09^{\mathrm{a}} \pm \\
0.075^{\mathrm{a}}\end{array}$ & $61.77^{\mathrm{b}} \pm 0.43$ \\
\hline Wateractivity & $0.558^{\mathrm{a}} \pm 0.017$ & $0.599^{\mathrm{b}} \pm 0.001$ & $0.676^{\mathrm{c}} \pm 0.016$ & $0.544^{\mathrm{a}} \pm 0.012$ & $\begin{array}{c}0.748^{\mathrm{d}} \pm \\
0.034^{2}\end{array}$ & $0.603^{\mathrm{b}} \pm 0.007$ \\
\hline $\begin{array}{l}\text { Total dietary } \\
\text { fibers }\end{array}$ & $13.63^{\mathrm{f}} \pm 1.12$ & $11.95^{\mathrm{e}} \pm 2,22$ & $9.97^{\mathrm{c}} \pm 0,45$ & $10.6^{\mathrm{d}} \pm 1.02$ & $8.62^{\mathrm{b}} \pm 0.98$ & $7.81^{\mathrm{a}} \pm 1.1$ \\
\hline $\begin{array}{l}\text { Insoluble } \\
\text { dietary fibers }\end{array}$ & $8.98^{\mathrm{f}} \pm 0,93$ & $7.99^{\mathrm{e}} \pm 2,02$ & $5.6^{\mathrm{a}} \pm 0,22$ & $7.82^{\mathrm{d}} \pm 1,35$ & $6.46^{\mathrm{b}} \pm 0,98$ & $6.65^{\mathrm{c}} \pm 0,78$ \\
\hline $\begin{array}{l}\text { Soluble dietary } \\
\text { fibers }\end{array}$ & $4.65^{\mathrm{f}} \pm 0,24$ & $3.96^{\mathrm{d}} \pm 0,2$ & $4.37^{\mathrm{e}} \pm 0,23$ & $2.78^{\mathrm{c}} \pm 0,33$ & $2.16^{\mathrm{b}} \pm 1,09$ & $1.16^{\mathrm{a}} \pm 0,18$ \\
\hline Ash $^{(\mathrm{a})}$ & $2.63^{\mathrm{bc}} \pm 0,00$ & $2.24^{\mathrm{a}} \pm 0.125$ & $2.60^{\mathrm{bc}} \pm 0.005$ & $2.37^{\mathrm{ab}} \pm 0.04$ & $\begin{array}{c}2.41^{\mathrm{ab}} \pm \\
0.175^{\mathrm{b}}\end{array}$ & $2.88^{\mathrm{c}} \pm 0.025$ \\
\hline Totalsugars $^{(\mathrm{a})}$ & $71.81^{\mathrm{a}} \pm 1.9$ & $81.33^{\mathrm{b}} \pm 1.3$ & $74.46^{\mathrm{c}} \pm 2,1$ & $67.4^{\mathrm{a}} \pm 0.06$ & $68.45^{\mathrm{e}} \pm 1.02$ & $65.30^{\mathrm{f}} \pm 0.75$ \\
\hline Total phenolic $^{(\mathrm{b})}$ & $249.290^{\mathrm{b}} \pm 0.005$ & $171.390^{\mathrm{a}} \pm 0.004$ & $224.74^{\mathrm{b}} \pm 0.01$ & $353.92^{\mathrm{c}} \pm 0.03$ & $\begin{array}{c}265.78^{\mathrm{b}} \pm \\
0.002\end{array}$ & $222.95^{\mathrm{b}} \pm 0.007$ \\
\hline $\begin{array}{l}\text { Total } \\
\text { Flavonoids }\end{array}{ }^{(\mathrm{b})}$ & $71.260^{\mathrm{b}} \pm 0.0021$ & $47.788^{\mathrm{a}} \pm 0.0043$ & $45.044^{\mathrm{a}} \pm 0.0007$ & $84.956^{\mathrm{c}} \pm 0.0021$ & $\begin{array}{c}53.047^{\mathrm{a}} \pm \\
0.0014\end{array}$ & $\begin{array}{c}43.280^{\mathrm{a}} \pm \\
0.0007\end{array}$ \\
\hline
\end{tabular}

Means $\pm S D(n=3)$. Values within the same row, followed by the same letter, are not statistically different ( $p<0.005)$ as measured by Student - Newman-Keuls. (a): g/100g dry weight, (b): mg gallic acid equivalents (GAE) /100g dry weight , (c): $\mu \mathrm{g}$ quercetin equivalent (QEQ)/100g dry weight.

showed high content of total sugars ( $65.30-81.33 \%$ dry matter basis) and significant amounts of total dietary fibers( TDF) ( 7.81- $13.63 \%$ dry matter basis ) and low contents of ash ( $2.24-2.88 \%$ dry matter basis). Analysis of variance of total sugars, dietary fibers (DF) and ash revealed significant difference $(p<0.05)$ between various cultivars. Hasnaoui et al. (2011) reported that the sugar fraction of date flesh of cvs. Assiane, Boufeggous, Boufeggousgharas and Mejhoul was essentially formed by reducing sugars (glucose and fructose in comparable proportion) in except of cv. Aziza bouzid characterized by its richness of sucrose. The low sugar content of Mejhoul and Boufeggousgharas cultivars can be explained by non enzymatic browning during storage favorite by their high amount of water. In except for cv. Mejhoul 1 that presented high value of water activity (0.748), the studied dates had a relatively low $a_{w}$ value, ranging between 0.544 (cv. Boufeggousgharas) to 0.676 (cv. Boufeggous) $(P<0.05)$. This low $a_{w}$ allowed the protection of dates from all bacterial alterations.

The studied date fruit presented total dietary fiber (TDF) content in the range $7.81-13.63 \mathrm{~g} / 100 \mathrm{~g}$ dry weight basis (Table 1). Assiane cultivar presented the highest value $(13.63 \%)$ followed by Aziza bouzid and Boufeggousgharas cultivars, while the Boufeggous and Mejhoul cultivars had the lowest values. Insoluble dietary fiber (IDF) was the major fraction, ranging between $5.6 \%$ (cv. Boufeggous) and $8.98 \%$ (cv. Assiane). Holland et al. (1991) reported that TDF values were about $9-11 \%$ using Southgate method and 5- $6 \%$ for Englyst method. Thus, our results are in the same range with those given by the Southgate method and higher than the upper estimate for Englyst method. Alshahib and Marshall found that the percentage of TDF of 13 date's varieties from various countries was in the range of $6.4-11.5 \%$, depending on the varieties and the degree of ripeness. Besbeset al.
(2008) reported that TDF contents from second - grade dates (from Degach region in Tunisia) of cvs. Allig, Degletnour and Kentichi were 8.70, 7.95 and $18.83 \mathrm{~g} /$ $100 \mathrm{~g}$ dry matter basis, respectively. While, Elleuch et al. (2008) found that cvs. Degletnour and Allig date byproducts, from the same region, contained higher amounts of TDF: $14.4 \%$ and $18.4 \%$ respectively. The differences observed between results of the two studies can be explained by differences of texture of date used in the experiments and differences caused by season, local variations in conditions and time of harvesting and storage.

Analysis of variance of total phenolic content showed a significant difference $(P<0.05)$ between the studied date'scultivars and ranged from $171.4 \mathrm{mg}$ of GAE /100 g to $353.92 \mathrm{mg}$ of $\mathrm{GAE} / 100 \mathrm{~g}$ dry weight basis). cv. Boufeggousgharas had the higher amount of total phenolic (353.92 $\mathrm{mg}$ of GAE/100 $\mathrm{g}$ dry weight basis) followed by cv. Mejhoul1 (265.78 mg of GAE/100g dry weight basis), cv. Assiane (249.29 mg of GAE/100 g dry weight basis), cv. Boufeggous (224.74 mg of GAE/100g dry weight basis) and cv. Mejhoul $2(222.95 \mathrm{mg}$ of GAE/100g dry weight basis). Aziza bouzid cultivar showed the lowest level of total phenolics content (171.4 $\mathrm{mg}$ of GAE/100g dry weight basis). Besbeset al. (2008) reported similar results for Allig, Degletnour and Kentichi date cultivars from Tunisia $(431.5 \mathrm{mg} \mathrm{GAE} / 100 \mathrm{~g}, 681.8$ $\mathrm{mg} \mathrm{GAE} /$ and $280.6 \mathrm{mg}$ GAE/ $100 \mathrm{~g}$ dry weight basis respectively). Al-Farsi et al. (2007) reported total phenolicvalues between 172 and $246 \mathrm{mg}$ of GAE/ 100 $\mathrm{mg}$ fresh weight for Omani dates. Wu et al. (2004) reported higher values of total phenolic for tow date cultivars studied (572 and $661 \mathrm{mg}$ of GAE/100 mg fresh weight). Sanchez-Zapata et al. (2011) found that cv. Mejhoul date paste also showed a high amount of total phenolics (225 mg GAE/100 g fresh weight). However, 
Table 2. Chemical composition of studied dates fiber concentrates (DFC)

\begin{tabular}{|l|l|l|l|l|l|l|}
\hline Contents & Assiane & Aziza bouzid & Boufeggous & Boufeggousgharas & Mejhoul 1 & Mejhoul 2 \\
\hline Dry matter (\%) & $87.71^{\mathrm{a}} \pm 0.18$ & $90.21^{\mathrm{d}} \pm 0.06$ & $89.74^{\mathrm{c}} \pm 0.01$ & $95.57^{\mathrm{f}} \pm 0.69$ & $91.89^{\mathrm{a}} \pm 0.07$ & $89.30^{\mathrm{b}} \pm 0.005$ \\
\hline Total dietaryfibers (a) & $90.76^{\mathrm{a}} \pm 2.02$ & $95.23^{\mathrm{e}} \pm 1.001$ & $92.91^{\mathrm{d}} \pm 2,016$ & $92.85^{\mathrm{c}} \pm 1.4$ & $92.91^{\mathrm{d}} \pm 2.51$ & $91.40^{\mathrm{b}} \pm 1.75$ \\
\hline Insoluble dietaryfibers(a) & $88^{\mathrm{c}} \pm 1.09$ & $85.82^{\mathrm{a}} \pm 0.15$ & $86.71^{\mathrm{b}} \pm 2.05$ & $89.14^{\mathrm{d}} \pm 0.68$ & $86.92^{\mathrm{b}} \pm 0.8$ & $90.70^{\mathrm{a}} \pm 0.003$ \\
\hline Soluble dietaryfibers (a) & $2.76^{\mathrm{b}} \pm 0.5$ & $9.41^{1} \pm 0.45$ & $6.2^{\mathrm{a}} \pm 0.12$ & $3.71^{\mathrm{c}} \pm 0.16$ & $5.99^{\mathrm{a}} \pm 0.2$ & $2^{\mathrm{a}} \pm 0.92$ \\
\hline Total sugars(a) & 0 & 0 & 0 & 0 & 0 & 0 \\
\hline Total phenolic(b) & $1.02^{\mathrm{a}} \pm 0,00$ & $0.55^{\mathrm{a}} \pm 0.125$ & $0.74^{\mathrm{c}} \pm 0.005$ & $0.93^{\mathrm{a}} \pm 0.04$ & $1.06^{\mathrm{e}} \pm 0.175$ & $0.64^{\mathrm{b}} \pm 0.025$ \\
\hline Total Flavonoids (c) & $1.06^{\mathrm{b}} \pm 0,00$ & $0.66^{\mathrm{a}} \pm 0.125$ & $0.73^{\mathrm{a}} \pm 0.005$ & $1.39^{\mathrm{c}} \pm 0.04$ & $0.98^{\mathrm{b}} \pm 0.175$ & $0.72^{\mathrm{a}} \pm 0.025$ \\
\hline Protein (a) & $10.40^{\mathrm{a}} \pm 0.03$ & $11.19^{\mathrm{a}} \pm 0.125$ & $8.47^{\mathrm{a}} \pm 0.05$ & $13.59^{\mathrm{f}} \pm 0.05$ & $9.02^{\mathrm{b}} \pm 0.175$ & $9.33^{\mathrm{c}} \pm 0.09$ \\
\hline Fats (a) & $1.13^{\mathrm{c}} \pm 0,95$ & $0.98^{\mathrm{ab}} \pm 0.089$ & $1.08^{\mathrm{b}} \pm 0.01$ & $0.97^{\mathrm{a}} \pm 0.098$ & $1^{\mathrm{b}}$ & $1.011^{\mathrm{b}}$ \\
\hline Ash (a) & $2.71^{\mathrm{a}} \pm 0.45$ & $3.53^{\mathrm{bc}} \pm 0.32$ & $4.035^{\mathrm{c}} \pm 1$ & $3.5^{\mathrm{b}} \pm 0.98$ & $3.03^{\mathrm{bc}} \pm 0$. & $3.035^{\mathrm{ab}} \pm 0.007$ \\
\hline
\end{tabular}

Means $\pm S D(n=3)$. Values within the same row, followed by the same letter, are not statistically different $(p<0.005)$ as measured by Student - Newman-Keuls. (a): g/100g dry weight, (b): $\mathrm{mg}$ gallic acid equivalents (GAE) $/ 100 \mathrm{~g}$ dry weight, (c): $\mu \mathrm{g}$ quercetin equivalent (QEQ)/ $100 \mathrm{~g}$ dry weight.

Mansouri et al. (2005) who studied seven Algerian date palm fruits and Biglari et al. (2009) who studied Iranian date's fruits found much lower total phenolic contents (2.49 - $8.36 \mathrm{mg} \mathrm{GAE} / 100 \mathrm{~g}$ for Algerian date fruits and 2.89 - $6.41 \mathrm{mg} \mathrm{GAE} / 100 \mathrm{~g}$ for Iranian varieties). These variations in total phenolic contents could be related to various factors. One such factor may be the difference of genetic potential of individual cultivars for polyphenol biosynthesis (Kallithraka et al., 2004). Maturity, season, geographic origin, fertilizer, soil type, storage conditions and amount of sunlight received may also be critical in this respect (Al-Farsi et al., 2007).

Total flavonoids content (TFC) of studied date varied significantly $(p<0.05)$ from 43.28 to $84.95 \mathrm{mg}$ in term of quercetin equivalents/ $100 \mathrm{~g}$ dry weight. The order of TFC of dates was: Mejhoul 2 <Boufeggous< Aziza bouzid<Mejhoul $1<$ Assiane<Boufeggousgharas. These values were higher than those reported by Biglariet al. (2008) for Iranian date varieties in except of Kharak cultivar that contained higher TFC $(81.7 \mathrm{mg}$ of catechin equivalent (CEQ) / 100g dry sample). For seven different varieties of ripe date palm fruits from Algeria, different types of flavonoids were identified mainly flavones, flavanones and flavonol glycosides (Mansouriet al., 2005).

Chemical composition analysis of date fiber concentrates (DFC)

Chemical composition and yields of the DFC obtained are given in Table 2 and 3 respectively. DFC exhibited low moisture content (Table 2) ranged from $4.43 \%$ (cv. Boufeggousgharas) to $12.29 \%$ (cv. Assiane) but showed higher amounts of TDF ranging between $90.76 \%$ (cv. Assiane) and 95.23 \% ( cv. Aziza bouzid) which is close to levels measured in DFC from cvs. Degletnour (22\%) and Allig (92\%) date's fruits from Tunisia (Elleuch et al., 2008). Our results of TDF are notably higher than those reported in Mango dietary fiber $28.1 \%$ (Vergara et al., 2007) and in grape skins (54.1- 64.6\%) (Bravo \&Saura, 1998). Studied DFC contained a higher proportion of insoluble dietary fibers (IDF) ranging from $85.82 \%$ (cv. Aziza bouzid) to $90.70 \%$ (cv. Mejhoul 2) and lower content of soluble dietary fibers (SDF) ranging between 2 (cv. Mejhoul 2) and $9.41 \%$ (cv. Aziza bouzid). The differences between IDF and SDF contents of studied DFC were significant $(p<0.05)$ as exhibited by StudentsNewman Keuls test. Similar pattern has been reported for other fiber preparations, such as citrus peel fibers (47.6 $\%$ IDF and $9.4 \%$ SDF) (Chau \& Huang, 2003), guava fiber (39.2 - 50.1 \% IDF and 1.8 \% SDF) (Jimenez et al., 2001a; Jimenez et al., 2001b). For certain Food applications, DFC should have a balanced content of soluble and insoluble fraction, in the case of mango dietary fiber, the two fiber types are present at almost equal levels $13,8 \%$ (IDF) and 14,25\% (SDF) (Vergara et al., 2007). The extraction yield of TDF varied significantly $(p<0.05$ ) from $51.6 \%$ (cv. Assiane) to $72.55 \%$ (cv. Mejhoul 2).

The extraction yield (table 3 ) of SDF varied between 4.6 (cv. Assiane) and $15.44 \%$ (cv. Aziza bouzid). The yield of IDF ranged from 69.81 to $98 \%$. Dry matter yield varied also significantly between the cultivars $(p<0.05)$. In fact, DFC from Assiane cultivar showed higher level $(7.75 \%)$. This can be explained by the fact that cv. Assiane has higher IDF amounts than the other cultivars (Table 1). Protein content is an important parameter in a dates fibers concentrates, ranging between $8.47 \%$ (cv.

Table 3. Evaluation of different types of extract yields

\begin{tabular}{|l|l|l|l|l|l|l|}
\hline Yield \% & Assiane & Aziza bouzid & Boufeggous & Boufeggousgharas & Mejhoul 1 & Mejhoul 2 \\
\hline Dry matter & $7.75^{\dagger} \pm 1$ & $6.5^{\mathrm{C}} \pm 1.03$ & $7.3^{\mathrm{e}} \pm 2.06$ & $7,07^{\mathrm{d}} \pm 1.13$ & $5^{\mathrm{a}} \pm 2.4$ & $6.2^{\mathrm{b}} \pm 1,7$ \\
\hline Total fibers & $51.60^{\mathrm{a}} \pm 0.3$ & $51.80^{\mathrm{b}} \pm 0.05$ & $68.03^{\mathrm{e}} \pm 0.34$ & $61.93^{\mathrm{d}} \pm 0.001$ & $53.90^{\mathrm{c}} \pm 0.85$ & $72.55^{\dagger} \pm 0.01$ \\
\hline Insoluble DF & $75.94^{\mathrm{c}} \pm$ & $69.81^{\mathrm{b}} \pm$ & $98.03^{\dagger} \pm$ & $80.60^{\mathrm{d}} \pm$ & $67.27^{\mathrm{a}} \pm$ & $84.56^{\mathrm{e}} \pm$ \\
\hline Soluble DF & $4.6^{\mathrm{b}} \pm 3.15$ & $15.44^{\dagger} \pm 1.03$ & $10.35^{\mathrm{d}} \pm 1.34$ & $9.43^{\mathrm{c}} \pm 0,06$ & $13.86^{\mathrm{e}} \pm 0.02$ & $3.74^{\mathrm{a}} \pm 2.13$ \\
\hline Proteins & $23.36^{\mathrm{e}} \pm 1.9$ & $18^{\mathrm{c}} \pm 1.25$ & $21.77^{\mathrm{d}} \pm 1.04$ & $39.38^{\dagger} \pm 0.008$ & $13.71^{\mathrm{a}} \pm 1.6$ & $17.38^{\mathrm{b}} \pm 1.00$ \\
\hline
\end{tabular}
$(p<0.005)$ as measured by Student - Newman-Keuls. 
Indian Journal of Science and Technology

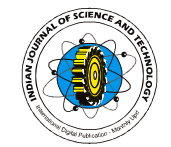

Table 4. Efficient concentration (EC50) and antiradical efficiencies $(A E)$ of DF concentrate

\begin{tabular}{|l|l|l|l|}
\hline Cultivars & \multicolumn{1}{|l|}{$\mathrm{I}_{50}(\mathrm{~g} / \mathrm{ml})$} & $\mathrm{EC}_{50}{ }^{\mathrm{A}}(\mathrm{g} / \mathrm{mg} \mathrm{DPPH})$ & $\mathrm{AE}^{\mathrm{B}}$ \\
\hline Assiane & $0.0056 \pm 0.002$ & $0.141 \pm 0.007$ & $7.09^{\mathrm{I}} \pm 0.856$ \\
\hline Aziza bouzid & $0.022 \pm 0.0316$ & $0.548 \pm 0.058$ & $1.824^{\mathrm{b}} \pm 0.789$ \\
\hline Boufeggous & $0.0315 \pm 0.002$ & $0.790 \pm 0.397$ & $1.265^{\mathrm{a}} \pm 5.10$ \\
\hline Boufeggousgharas & $0.0106 \pm 0.0046$ & $0.265 \pm 0.022$ & $3.773^{\mathrm{C}} \pm 1.318$ \\
\hline Mejhoul 1 & $0.0094 \pm 0.003$ & $0.236 \pm 0.001$ & $4.237^{\mathrm{d}} \pm 0.10$ \\
\hline Mejhoul 2 & $0.0086 \pm 0.063$ & $0.217 \pm 0.015$ & $4.608^{\mathrm{e}} \pm 1.341$ \\
\hline
\end{tabular}

Results are means $\pm S D$.values of the same column, followed by the same letter, are not statistically different $(P<0.05)$ as measured by Student - Newman-Keuls Boufggous) and $13.59 \%$ (cv. Boufeggousgharas). These values are also higher as compared to other fibers such as Mango: 4.2 \% (Vergara et al., 2007) and Citrus sinensis peel: $2.2 \%$ (Chau \& Huang, 2003); but with similar values to those obtained by Bravo and SauraCalixto (1998) for grape skins: 11.6- 14.4\%. Similar values have been reported for other DFC from other date's cultivars such as cvs. Allig and Degletnour (Elleuchet al., 2008) Differences between proteins content of different dates fibers concentrates are due to varieties and methods of analysis and extraction. The yield of protein varied between $13.71 \%$ (cv. Mejhoul1) and $39.38 \%$ (cv. Boufeggousgharas). This can be explained by the presence of a portion of protein that binds strongly to DF: cell wall (O'Neill and Selvendran, 1985) and another portion that is insoluble (initially insoluble) and/ or denatured by hot water during extraction of DF). The ash content of DFC varied between $2.71 \%$ (cv. Assiane) and $4.035 \%$ (cv. Boufeggous). These values are lower compared to the other fruits fiber concentrates such as grape skins (5.7$9.2 \mathrm{~g} / 100 \mathrm{~g}$ (Bravo \& Saura-Calixto, 1998; Elleuch et al., al., 2002; Guoet al., 2003).

(June 2012)

ISSN: 0974- 6846

Total flavonoid content (TFC) of date fiber concentrates varied also significantly between cultivars,

from 0.66 (cv. Aziza bouzid) to 1.39 (cv. Boufeggousgharas) $\mu \mathrm{g}$ in term of quercetin /g dry weight basis. Fruits with high antioxidant capacity generally contain more antioxidant compounds and most of these has been showed to be phenolic compounds and in particular flavonoids (Wang et al., 1996; Connor et

The averages of antiradical efficiency (AE) based on DPPH (diphénylpicryl-hydrayl) assay was tested in extractable polyphenols obtained from DFC are given in table 4. The DFC of cv. Assiane showed the highest level of $\mathrm{AE}\left(7.09 \times 10^{-3}\right)$ while $\mathrm{cv}$. Boufeggous date exhibited the lowest level $\left(1.265 \times 10^{-3}\right)$. The order of AE of DFC was : Boufeggous< Aziza bouzid <Boufeggousgharas $<$ Mejhoul $1<$ Mejhoul $2<$ Assiane. Analysis of variance (ANOVA) showed strong difference between all types of DFC since the $p<0.0001$ indicating that the types of dates are different based on the antiradical efficiency .Our results are relatively in the range with those determined in fibers extracted from guava fruit $\left(7 \times 10^{-3}\right.$ $9 \times 10^{-3}$ ) (Jimenez et al., 2001a; Jimenez et al., 2001b) but lower than the value obtained by Vergara et al. (2007) for mango $\operatorname{DF}\left(15 \times 10^{-3}\right)$.

Technological properties of DFC

Water holding capacities (WHC), oil holding capacity $(\mathrm{OHC})$, Emulsion capacity (EC) and Emulsion stability (ES) are given in Table 5.

Table 5. Technological properties (water holding capacity (WHC), oil holding capacity (OHC), emulsion capacity and emulsion stability) of DFC.

\begin{tabular}{|l|l|l|l|l|l|l|}
\hline Pameterar & Assiane & Aziza bouzid & Boufeggous & Boufeggous gharas & Mejhoul 1 & Mejhoul 2 \\
\hline $\begin{array}{l}\text { Emulsion capacity } \\
\text { (ml /100 ml emulsion) }\end{array}$ & $22.5^{\mathrm{b}} \pm 0.55$ & $22.5^{\mathrm{b}} \pm 0.61$ & $17.5^{\mathrm{a}} \pm 2.08$ & $22.5^{\mathrm{b}} \pm 0.6$ & $22.5^{\mathrm{b}} \pm 0,5^{2}$ & $23^{\mathrm{c}} \pm 1,03$ \\
\hline $\begin{array}{l}\text { Emulsion stability } \\
\text { (ml } / 100 \text { ml emulsion) }\end{array}$ & $38^{\mathrm{e}} \pm 2.828$ & $36.25^{\mathrm{c}} \pm 1.06$ & $34.5^{\mathrm{a}} \pm 0.707$ & $37^{\mathrm{d}} \pm 1.5$ & $37^{\mathrm{d}} \pm 0.98$ & $36^{\mathrm{b}} \pm 2,4$ \\
\hline WHC(g water/100g) & $6.55^{\mathrm{c}} \pm 0.065$ & $7.91^{\mathrm{d}} \pm 0.50$ & $7.98^{\mathrm{e}} \pm 0.03$ & $6.08^{\mathrm{a}} \pm 0.075$ & $6.62^{\mathrm{b}} \pm 0.1$ & $6.08^{\mathrm{a}} \pm 0.36$ \\
\hline $\mathrm{OHC}(\mathrm{g}$ water/100g) & $5.51^{\mathrm{c}} \pm 0.76$ & $5.45^{\mathrm{b}} \pm 0,58$ & $5.70^{\mathrm{d}} \pm 0.61$ & $5.34^{\mathrm{a}} \pm 0.53$ & $5.44^{\mathrm{b}} \pm 0,06$ & $6.38^{\mathrm{e}} \pm 0,512$ \\
\hline
\end{tabular}

Means $\pm S D(n=3)$. Values within the same row, followed by the same letter, are not statistically different $(P<0.005)$ as measured by Student - Newman-Keuls.

2008) reported $2 \%$ of ash for DFC from cvs. Degletnour and Allig.

The total phenolics content (TPC) in date fiber concentrates varied significantly between cultivars $(p<$ $0.05)$.it varied from 0.55 to $1.06 \mathrm{mg}$ galic acid equivalent / $\mathrm{g}$ dry weight basis. The highest TPC was obtained in cv. Mejhoul1 DFC and the lowest TPC was found in the cv. Aziza bouzid DFC (Table 3). Our results are several folds lower than other DFC such as mango $(16.1 \mathrm{mg} / \mathrm{g}$ dry sample), Mexican lime peel (10.55 and $19.9 \mathrm{mg} / \mathrm{g}$ ) Ubando-Rivera et al. (2005) and in commercial grape skin fiber $(20 \mathrm{mg} / \mathrm{g}$ ) Saura-Calixto (1998).
The result of WHC shows that cvs. Boufeggous and Aziza bouzid had the highest WHC $(7.98 \mathrm{~g}$ of water/g dry weight) and $(7.91 \mathrm{~g}$ water $/ \mathrm{g}$ dry weight) respectively, followed by cvs. Mejhoul 1(6.08 g water /g dry weight), Boufeggousgharas (5.82 g water /g dry sample), Assiane (5.74 g water $/ \mathrm{g}$ dry sample) and Mejhoul 2 (5.43 g water /g dry sample). Those result are similar to those reported by Elleuch et al. (2008) for Allig and Degletnour cultivars (7 and $6.4 \mathrm{~g}$ water/g dry sample respectively) but lower than WHC of dry citrus peel fiber ranging between 15.5 and $16.7 \mathrm{~g}$ of water/g of dry sample (Chau\& Huang, 2003). Dietary fiber has and important effect on this technological property because it holds water by
Research article

(C)Indian Society for Education and Environment (iSee)
"Moroccan date"

http://www.indjst.org
A.Hasnaoui et al.

Indian J.Sci.Technol. 
adsorption and absorption phenomena. Some water is also retained outside the fiber matrix (free water). This property is related to the chemical and physical structure of the plant polysaccharides (Sanchez et al., 2011). These hydration properties of date paste determine their optimal usage levels in foods as they provide desirable texture properties. $\mathrm{OHC}$ is another important parameter which in DFC ranged between $5.51 \mathrm{~g}$ of oil/g dry sample (Assiane) and $6.38 \mathrm{~g}$ of oil/g dry sample. These values were lower than those obtained by Elleuch et al. (2008) for cvs. Allig and Degletnour ( 9.7g oil/g sample) but higher than those reported in other DFC, e.g. mango fiber concentrates (1- $1.5 \mathrm{~g}$ of oil/ $\mathrm{g}$ of dry sample) (Vergara et al., 2007) and some date by-product. As reported by Sanchez et al. (2010), OHC of Mejhoul date paste was $0.53 \mathrm{~g}$ of oil $/ \mathrm{g}$ of dry sample. In view of that, DFC may be suitable in products where emulsifying properties are not required. Emulsion capacity $(E C)$ is a molecule's ability to act as an agent that facilitates solubilization or dispersion of two immiscible liquids. Emulsion stability (ES) is the ability to maintain the integrity of an emulsion (Sanchez et al., 2010). Emulsion capacity of DFC was in the range of $17.5 \mathrm{ml} / 100 \mathrm{ml}$ (cv. Boufeggous) and $23.00 \mathrm{ml} / 100 \mathrm{ml}$ (cv.Mejhoul 2) and their ES was in the range of $35 \mathrm{ml} / 100$ $\mathrm{ml}$ (cv. Boufeggous) and $40 \mathrm{ml} / 100 \mathrm{ml}$ (cv. Assiane). This $\mathrm{EC}$ is lower than tiger nut fiber (70.33), chia fiber (53.26 $\mathrm{ml} / 100 \mathrm{ml}$ ), fiber-rich passion fruit powders $(52.58 \mathrm{ml} / 100$ $\mathrm{ml}$ ) and Phaseolus lunatus fibrous residue $(49.3 \mathrm{ml} / 100$ $\mathrm{ml}$ ) (Sanchez et al., 2010). The study of these properties shows that DFC could be used as technological ingredient in food to avoid syneresis, to stabilize products with a high percentage of fat and emulsions and to modify the texture and the viscosity of formulated products by virtue of their water holding capacity, oil holding capacity, emulsion capacity and stability.

\section{Conclusions}

This study showed that date flesh could be considered as potential source of sugar, fiber and phenolic compounds which have many health benefits and could be used for added value. DFC extracted from the five studied date cultivars contained high content of total dietary fibers. Date flesh can be successfully used to obtain a dietary fiber concentrates which is a potential source of valuable nutrients. The properties of this DFC suggested that it could be used in food industries as an important source of dietary fiber and natural antioxidants (polyphenol content) and as a functional ingredient for stabilization of food product with high content of fat and emulsion by virtue of their high WHC and OHC.

\section{References}

1. Ahmed IA and Ahmed AWK (1995) Chemical composition of date varieties as influenced by the stage of ripening. Food Chemi. 54, 305-309.

2. Aidoo KE, Tester RF, Morrison JE and MacFarlane D (1996) Thecomposition and microbial quality of prepacked dates purchased inGreater Glasgow. Int. J. Food Sci. \& Technol. 31, 433-438.
3. Al-Farsi M, Alaslvar C, Morris A, Baron M and Shahidi F (2005) Comparison of antioxidant activity, anthocyanins, carotenoids and phenolics of three native fresh and sundried date (Phoenix dactylifera L.) varieties grown in Oman. J. Agri. Food Chem. 53, 7592 -7599.

4. Al-Farsi M, Alasalvar C, Al-Abid M, Al-Shoaily K, Al-Amry $\mathrm{M}$ and Al-Rawahy $\mathrm{F}$ (2007) Compositional and functional characteristics of dates, syrups and their by-products. Food Chem. 104, 943-947.

5. Al-Hooti S, JS Sidhu and H Qabazard (1995) Studies on the physico-chemical characteristics of date fruits of five UAE cultivars at different stages of maturity. Arab Gulf J. 13, 553-569.

6. Al-Mukhtar MM (1994) Nutritional aspects of date with special reference to the tryptophan, lysine and dietary fiber content. M.Sc. Thesis, Glasgow, Strathclyde University.

7. AOAC (1997) Official methods of analyses. Association of official analytical chemist, Washington, DC.

8. Barreveld WH (1993) Date palm products, FAO agricultural services bulletin $\mathrm{N}^{\circ} 101$. Food \& Agri. Organiz. United Nations, Rome.

9. Besbes S, Drira L, Blecker C, Deroanne C and Attia H (2008) Adding value to hard date (<1>Phoenix dactylifera $</ \mid>$ L.): Compositional, functional and sensory characteristics of date jam. Food Chem. 112, 406-411.

10. Biglari F, FMA Akarkhi and EasaAM (2008) Antioxydant activity and phenolic content of various date palm (<|>Phoenix dactylifera</|>) fruits from Iran. Food Chem.107, 1636-1641.

11. Biglari F, AFM AlKarkhi and AM Easa (2009) Cluster analysis of antioxidant compounds in dates (Phoenix dactylifera): Effect of long-term cold storage. Food Chem. 112, 998-1001.

12. Borchani C, Besbes S, Blecker C, Masmoudi M, Baati R and Attia $H$ (2010) Chemical properties of 11 date cultivars and their corresponding fiber extracts. Afr. J. Biotechnol. 9, 4096-4105.

13. Bravo $L$ and Saura-Calixto $F$ (1998) Characterization of dietary fiber and the in vitro indigestible fraction of grape pomace. Am. J. Enology \& Viticulture. 49, 135-141.

14. Chau CF, Cheung PCK and Wong YS (1997) Functional properties of protein concentrate from three Chinese indigenous legume seeds. J. Agri. \& Food Chem. 45, 2500-2503.

15. Chau CF and Huang YL (2003) Comparison of the chemical composition and physicochemical properties of different fiber prepared from de peel of Citrus sinensis $\mathrm{L}$. Cv. Liucheng. J. Agri. \& Food Chem. 51, 2615-2618.

16. ConnorAM, Luby JJ, Hancock JF, Berkheimer $S$ and Hanson EJ (2002) Changes in fruits antioxidant activity among blueberry cultivars during cold-temperature storage. J. Agri. \& Food Chem. 50, 893-898.

17. El Arem A, Guidob F, Behijaa SE, Manelc I and Nesrine $Z$ (2011)Chemical and aroma volatile compositions of date palm (Phoenix dactylifera L.) fruits at three maturation stages. Food Chem. 127,1744-1754.

18. Elleuch M, Besbes S, Roiseux O, Blecker C, Deroanne C, Drira NE and Attia H (2008) Date flesh: Chemical 
composition and characteristics of the dietary fiber. Food Chemi. 111, 676-682.

19. Englyst HN, Quigley ME and Hudson GJ (1994) Determination of dietary fiber as non starch polysaccharides with gag-liquid chromatographic or spectrophotometric measurement of constituent sugars. Analyst. 119, 1497-1509.

20. FAOSTAT (2009) Agro-statistics. Database. Rome: Food \& Agri. Organiz. United Nations.

21. Guo A, Yang J, Wei J, Li Y, Xu J and Jaing Y (2003) Antioxydant activities of peel, pulp and seed fractions of common fruit as determined by FRAP assay. NutrtionRes. 23, 1719-1726.

22. Hakkou A and Bouakka M (2004) L'Oasis de Figuig: état actuel de la palmeraie et incidence de la fusariose vasculaire. Sécheresse.2, 147- 158.

23. Hasnaoui A, Elhoumaizi MA, Hakkou A, Wathelet B and Sindic M (2011) Physico-chemical characterization, classification and quality evaluation of date palm fruits of some Moroccan cultivars. J. Sci. Res. 3,139-149.

24. Holland G, Welch AA, Unwin DD, Buss DH, Paul AA and Southgate DAT (1991) The Composition of Foods. $5^{\text {th }}$ Ed.,Royal Soc. Chem.Campridge, UK, ISBN: 9780851863917. pp: 475.

25. Ismail B, Haffar I, Baalbaki R, Mecheref $Y$ and Henry J (2006) Physicochemical characteristics and total quality of five date varieties grown in the United Arab Emirates. Int. J. Food Sci. \& Technol. 41, 919-926.

26. Jimenez-Escrig A, Jimenez-Jimenez I, Pulido $R$ and Saura-Calixto F (2001a) Antioxidant activity of fresh and processed edible seaweeds. J. Agri. \& Food Chem. 81, 530-534.

27. Jimenez-Escrig A, Rincon M, Pulido R and Saura-Calixto F (2001b) Guava fruit (Psidiumguajava L.) as a new source of antioxidant dietary fiber. J. Agri. \& Food Chem. 49, 5489-5493.

28. Kallithraka S, Mohdaly AAA, Makris DP and Kefalas $P$ (2004) Determination of major anthocyanin pigments in Hellenic native grape varieties (Vitisvinifera sp.): Association with antiradical activity. J. Food Comp. Anal. 18, 375-386.

29. Lin MJY, Humbert ES and Sosulski FW (1974) Certain functional properties of sun flower meal products. J. Food Sci. 39, 368-370.

30. Mansouri A, Embared G, Kokkalou E and Kefalas P (2005) Phenolic profile and antioxidant activity of the Algerian ripe date palm fruit (Phoenix dactylifera). Food Chem. 89, 411-420.

31. Masuda TS, Yonemori Y, Oyama Y, Takeda and Tanaka $T$ (1999) Evaluation of the antioxidant activity of environmental plants: Activity of the leaf extracts from seashore plants. J. Agri. \& Food Chem., 47, 1749-1754.

32. Miller GL (1959) Use of dinitrosalycilic acid reagent for determination of reducing sugars. Anal. Chem. 31, 426428.

33. O'Neill MA and Selvendran RR (1985) Hemicellulosic complexes from the cell walls of runner beans (Phaseoluscoccineu). Biochem. J. 227, 475- 481.

34. Robertson JA, de Monredon FD, Dysseler P, Guillon F, Amado R and Thibault JF (2000) Hydratation properties of dietary fiber and resistant starch: A European collaborative study. LWT. 33, 72-79.

35. Sanchez-Moreno C, Larrauri JA and Saura-Calixto F (19980 A procedure to measure the antiradical efficiency of polyphenols. J. Sci. Food \& Agri. 76, 270-276.

36. Sanchez-Zapata E, Fernandez-Lopez J, FuentesZaragoza MPE, Sendra E, Sayas E and Perez-Alvarez JA (2011) Technological properties of date paste obtained from date by-products and its effect on the quality of a cooked meat product. Food Res. Int. 44, 2401-2407.

37. Sanchez-Zapata E, Fuentes-Zaragoza E, FernandezLopez J, Sendra E, Sayas E, Navarro C and PerezAlvarez JA (2010) Preparation of dietary fiber powder from tiger nuts (Cyperusesculentus) milk ("horchata") byproducts and its physicochemical properties. J. Agri. \& Food Chem. 57, 7719-7725.

38. Saura-Calixto $F(1998)$ Antioxidant dietary fiber product: A new concept and a potential food ingredient. J. Agri. \& Food Chem. 46, 4303- 4306.

39. Sawaya WN, Khalil JK, Safi WM and Al-Shalat A (1983) Physical and chemical characterization of three Saudi date cultivars at various stages of development. Can. Inst. Food Sci. Technol. J. 16, 87-93.

40. Ubando-Rivera J, Navarro-Ocana A and Valdivia-Lopez MA (2005) Mexican lime peel: Comparative study on contents of dietary fiber and associated antioxidant activity. Food Chem. 89, 57-61.

41. Vergara-Valencia N, Granados-Pereza E, AgamaAcevedo E, Tovarb J, Rualesc J and Bello-Perez LA (2007) Fiber concentrates from mango fruit: Characterization, associated antioxidant capacity and application as a bakery product ingredient. LWT. 40, 722 $-729$.

42. Wang $\mathrm{H}$, Cao $\mathrm{G}$ and Prior RL (1996) Total antioxidant capacity of fruits. J. Agri. \& Food Chem. 44, 701-705.

43. Wu X, Beecher GR, Holden JM, Haytowitz DB, Gebhardt SE and Prior RL (2004) Lipophilic and hydrophilic antioxidant capacities of common foods in the United States. J. Agri. \& Food Chem. 52, 4026-4037.

44. Yasumatsu K, Sawada K and Moritaka K (1972) Whipping and emulsifying properties of soybean products. J. Agri. \& Food Chem. 36, 719-737.

45.Zhishen J, Mengcheng T and Jianming W (1999) The determination of flavonoid contents in mulberry and their scavenging effects on superoxide radicals. Food Chem. 64, 555-559.
Research article

(C)Indian Society for Education and Environment (iSee)
"Moroccan date" http://www.indjst.org
A.Hasnaoui et al. Indian J.Sci.Technol. 